doi: 10.3935/rsp.v26i3.1638

\section{THE INCLUSIVE ECONOMY: HOW TO BRING WEALTH TO AMERICA'S POOR}

\section{Michael D. Tanner}

Washington DC: Cato Institute, 2018., 250 str.

O malom broju važnih društvenih pojava kao što je siromaštvo i načinima njegovog ublažavanja postoje tako oprečna razmišljanja i stavovi političara, sociologa, socijalnih radnika, ekonomista i drugih stručnjaka. Iako se uglavnom svi slažu kako je siromaštvo ozbiljna osobna teškoća i velika prijetnja koja lako može ugroziti stabilnost i prosperitet društva, razlike se javljaju kod ocjena njegovih uzroka i pogotovo kod mjera njegovog ublažavanja. Jesu li siromašne osobe (barem djelomično) krive za svoj nezavidan položaj? Što i koliko društvo može pomoći siromašnima u njihovom izlasku iz neimaštine? Stručnjaci se često ne slažu oko učinkovitosti programa socijalne skrbi jer često ističu kako mjere socijalne skrbi izazivaju lijenost, potiču radnu neaktivnost, narušavaju oslanjanje na vlastite snage i stvaraju ovisnost o oblicima pomoći. Nadalje, usprkos razmjerno velikim izdvojenim sredstvima, stanje i oblici siromaštva uglavnom se slabo mijenjaju, a osobama koje su njime pogođene gotovo je nemoguć izlaz iz tog stanja. Stoga se opravdano postavlja pitanje - možemo li na neki način poboljšati svoja znanja o siromaštvu te pogotovo možemo li unaprijediti mjere njegovog ublažavanja? Konačno, mogu li se iskustva pojedinih zemalja, čije su razlike gotovo veće od sličnosti, primijeniti u drugim društvima?

Michael D. Tanner u svojoj novoj knjizi The Inclusive Economy: How to Bring Wealth to America's Poor (Gospodarstvo koje uključuje: kako obogatiti siromašne u Ame- rici), piše o stanju i načinima ublažavanja siromaštva u SAD-u, ali jasnoća i primjenjivost njegovih uvida sigurno zavređuje pozornost i u drugim državama. Knjiga počinje nizom priznanja koja mogu šokirati čitatelje, pogotovo one konzervativnog političkog usmjerenja. Tanner naglašava kako je siromaštvo jako ozbiljan problem u SAD-u za koji su izdvojena jako velika sredstva s upitnim učincima. Sustavni napori na poboljšanju stanja provedeni su u vrijeme mandata predsjednika Lyndona Johnsona kroz »Rat protiv siromaštva« kada se unutar programa »Veliko društvo« iz 1964. ogromnim dotacijama središnje države nastojalo pomoći siromašnima i nezaposlenima. Time se, istina, donekle ublažilo siromaštvo - jer čak ni savezna vlada nije mogla potrošiti toliko novca bez da je nešto dobila - ali su konačni učinci prilično slabi.

Knjiga je izuzetno jasno argumentirana i nepristrana. Tanner daje vrlo dojmljiv pregled povijesti siromaštva u SAD-u pri čemu pokazuje kako su pogrešna viđenja lijevog političkog ekstremizma u znatnom povećanju programa ublažavanja siromaštva, odnosno desnog u njihovom mogućem ukidanju. Snažnije oporezivanje bogatih i davanje tako prikupljenih sredstava siromašnima u dužem roku neće značiti njihov izlazak iz siromaštva zato što se time ne uklanjaju uzroci nastanka samog siromaštva. Koji su uzroci siromaštva? Je li siromaštvo posljedica činjenice što su jednostavno neki ljudi manje sposobni za natjecanje u gospodarstvu od drugih, ili su kulturološke odrednice u svijetu rada presudne što je značajan dio stanovništva u nepovoljnom položaju. Iako Tanner naizgled dolazi s liberalne strane, on nedvojbeno pokazuje kako su u SAD-u rasna represija i spolna diskriminacija ozbiljne odrednice javljanja siromaštva. Istina, u društvu je došlo do značajnih promjena u pravilima i stavovima u američkom društvu, još uvijek 
su manjine i žene mnogo izloženije riziku da budu siromašne nego što su to bijelci i muškarci.

Tanner, međutim, odbacuje ideju kako bi vlada trebala i mogla jednom zauvijek okončati siromaštvo. Posve nerealna utopija sigurno nije opcija, siromaštvo odražava osobne životne izbore, a na njega u značajnoj mjeri utječu mnogobrojni društveni čimbenici. Najkraće, siromaštvo se nikada ne može u potpunosti eliminirati, ali se $u$ značajnoj mjeri može ublažiti i država odgovarajućim mjerama znatno može pomoći pogođenim osobama da iz njega uspješno izađu. Gospodarski rast bio je pokretač koji je omogućio SAD-u i mnogim drugim razvijenim zemljama da izvuku većinu stanovništva iz siromaštva, ali su potrebne i popratne aktivnosti, ponajviše vezane uz jasne poticaje kako bi se poboljšao položaj siromašnih.

Iako u SAD-u postoje prilično brojni programi u novcu i naravi namijenjeni siromašnima (poput zdravstvene zaštite siromašnih Medicaid ili markice za hranu), oni najčešće ublažavaju posljedice neimaštine, a malo doprinose rješavanju uzroka. Ako samohrana majka gubi pravo iz odgovarajućeg programa jednom kada se uda, ona će gotovo sigurno ostati u izvanbračnoj zajednici kako bi i nadalje ostvarivala to pravo. Ako nezaposlena osoba gubi socijalne naknade ako se zaposli u službenom gospodarstvu, posve je očito kako će radije ostati izvan svijeta rada u službenom gospodarstvu. Rješenja nisu jednostavna niti se mogu lako ostvariti, ali već je značajan korak ako se pomoć u naravi (na primjer, markice za hranu) pretvore u novčana davanja jer se time ostvaruje veća transparentnost i jednostavnost sustava socijalne skrbi. Primatelji tako imaju veću moć i priliku da donose optimalne odluke na temelju svojih specifičnih okolnosti, a dobivena se sredstva mogu mnogo bolje iskoristiti.
SAD ima neslavni rekord po velikom broju osoba koje odslužuju zakonske kazne, pa dok je u SAD-u na 100 tisuća 700 njih u zatvoru, u Kanadi je to tek nešto više od 100, a u Sloveniji i Finskoj je znatno manje od 100. To je neproduktivno i skupo sa stanovišta države, a bez postojanja učinkovitih programa pomoći, bivši zatvorenici gotovo su prisiljeni rješavanje svojih potreba potražiti u nezakonitim aktivnostima. Stoga Tanner kao bitnu mjeru navodi reformu kaznenog pravosuđa, i to u svim fazama, počevši od kriminalizacije tek manjeg broja kaznenih djela jer se u SAD-u lako može završiti u zatvoru zbog zakašnjelog plaćanja režija ili neplaćanja kazne za nepropisno parkiranje pa sve do potrebe razvoja uključivanja bivših zatvorenika u svijet rada i društvo. Nadalje, mnogo osoba u SAD-u ne stječe odgovarajuće obrazovanje ili ispadaju iz obrazovanja tako da su skoro potpuno nezapošljive. Ujedno, kakvoća američkog obrazovnog sustava u najvećoj mjeri odražava sredinu gdje je smještena školska ustanova: odnosno, prilično dobro u bogatim četvrtima i vrlo loše u onima koje nastanjuju siromašni. Kako upisivanje u školu ovisi o mjestu stanovanja, siromašni prijavljuju netočnu adresu stanovanja što je zbog raširenosti postalo krivično djelo. Kao rješenje za te teškoće, autor predlaže stvarnu reforma obrazovanja, ponajviše omogućavanje više izbora i konkurencije među ustanovama naspram ulijevanja više novca u monolitni javni školski sustav.

Siromašni su često u nemogućnosti stanovati u boljim i skupljim četvrtima, a time su sužene i mogućnosti njihovog boljeg zapošljavanja kao i izgledi da će njihova djeca steći bolje obrazovanje. Na taj se način, siromaštvo prenosi na nove naraštaje pa Tanner ističe potrebu promišljanja zakona koji omogućavaju relativno smanjivanje troškova stanovanja i izbjegavanje izgradnje blokova socijalnih stanova koji dovode do getoizacije i pojačavaju zarobljenost $\mathrm{u}$ 
siromaštvu. Nadalje, u siromašnim četvrtima nedostaju poslovnice financijskih ustanova što siromašne stanovnike ne motivira na akumuliranje štednje, ali ih i prisiljava na traženje mogućih kredita kod zelenaša.

U cjelini, riječ je o izuzetno zanimljivom pristupu i razmatranju mnogih tema koje nisu naočigled povezane sve dok autor ne istakne veze. Ova knjiga trebala bi biti obvezno štivo za sve one koji su doista zainteresirani za razumijevanje mjera za okončanje siromaštva, ne samo u SAD-u, nego i u većini manje razvijenih zemalja. Pritom Tanner stvarno pristupa s otvorenim umom, posve svjestan kako će njegova analiza i preporuke biti izazov za bilo kojeg samozvanog stručnjaka koji je siguran kako već odavno poznaje sve odgovore i moguća rješenja.

\section{Predrag Bejaković}

Institut za javne financije 